\title{
Interrogating power and disrupting the discourse about Onslow and the \\ gas hubs
}

Abstract: When government statements talk about a secret deal with a multinational consortium that will see more than $\mathrm{A} \$ 250$ million spent on a town with a population of around 1000 people, questions need to be asked. Basic maths equates the spend to around $\$ 250,000$ a person and yet many people in the town are unhappy about the whole deal. Tracking Onslow was a collaboration between a university and a local government that used journalism as a methodology to document and interrogate the interaction between Chevron, the state and local governments and the Onslow community over a three-year period. This article focuses on the production of the lead feature of the final edition. It presents the published article and a reflexive exegesis that uses Foucault's ideas about power and knowledge to frame and evaluate the journalistic endeavour.

Keywords: Australia, collaborations, community media, exegeses, investigative journalism, journalism as research, mining, reflexivity, research methodologies, resource curse, student press

\section{KAYT DAVIES and KARMA BARNDON}

Edith Cowan University, Perth

\section{Introduction}

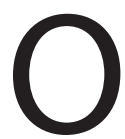

NSLOW is a small town on the coast of Western Australia in the resource-rich Pilbara region. Tracking Onslow was a collaborative venture between Edith Cowan University, in Perth, and the Shire of Ashburton, the local government that covers Onslow and three other Pilbara towns. The project used journalism to document physical and social changes in Onslow between 2012 and 2015. Over these years the A \$29 billion Wheatstone and $\mathrm{A} \$ 1.5$ billion Macedon, gas processing plants were under construction just a few kilometres from the town. Both projects are joint ventures. The Wheatstone JV is led by Chevron and Macedon by BHP Billiton. WA Government 
figures released in 2011 forecast that the town's population would grow from 600 to 2000 by 2016 (Powell, 2013), and the companies involved promised the town millions of dollars of infrastructure funding (Ottaviano, 2012). The State government also promised significant investment in Onslow (Premier's Office, 2014).

In his book on the context and practice of investigative journalism, Hugo de Burgh called journalism the 'tribune of the commoner, ... protect[ing] the public's right to know, to examine and to criticise' (2000, p. 6). In a similar vein, Julianne Schultz (1998) described journalism as the watchdog that barks to alert the public to corruption and undue influence, acting as a check and balance on government. Journalism textbooks are replete with statements such as these (Franklin et al, 2005; Lamble, 2013; Errington and Miragliotta, 2011), and Knight went as far as to say that 'journalists have professional and ethical responsibilities to look beyond what they have been told by those in authority' (2000, p. 48). From this perspective, these promises about what would happen in Onslow warranted media scrutiny.

The six editions of the Tracking Onslow magazine (produced twice yearly between mid-2012 and mid-2015) aimed to fulfil three political functions of journalism described by Errington \& Miragliotta (2011). These are: to produce a first draft of history; to provide and facilitate a 'town square' that enables the free exchange of views; and to perform the 'watchdog' role. These aims were explicitly stated in the editorial letters on the first page of each edition. For example:

This magazine is not a PR tool for the shire, for Chevron, for the Chamber of Commerce and Industry, or for any particular group in the community. Our aim instead is to do the things that journalism ideally should do, and one of these is to function as a town square where everyone's views are shared, so that questions can be answered and issues debated. (Davies, 2015, p. 1)

The project provided an opportunity for authentic, work-integrated learning for journalism students who travelled to Onslow and researched, wrote and assisted in the production of the magazine and its companion website. Davies (2014a) describes the pedagogy of the project in more detail. This article presents the lead feature of the final edition (reproduced at the end) and an exegesis. The published article sought to answer difficult questions not answered in previous editions and also to follow up and continue narrative threads commenced in those earlier editions. The exegesis comprises: a summary of the academic context of this work (including the Foucauldian notions of discourse and power that frame it); background information that led to conceptualisation of the lead article and notes on its production; and a discussion about whether, in this case, contemporary Australian journalism (as described by Lamble, 2004; 2013) has been shown to be able to fulfill the watchdog, town square and first draft of 
history functions amid corporate and government power struggles over control of the narrative.

\section{Part 1: The exegesis}

Conflicting discourse about the social, economic and environmental impacts of the Australian mining industry characterises the substantial body of academic literature on the subject. While the government (Barnett, 2010; Buswell, 2013) and industry representatives (Shann, 2012) have extolled the fiscal benefits of the so-called 'mining boom', other studies have identified inequities in wealth distribution and adverse social implications. (Brueckner et al, 2013; Chapman et al, 2014; Carrington \& Pereira, 2011). Researchers at the Australia Institute warn that the mining boom has created a 'two speed economy', by pushing up the exchange rate and cutting the export profits of trade-dependent sectors of the economy (Grudnoff, 2013). Downes et al (2014) from the Reserve Bank of Australia concur, saying that while the mining, construction and import industries have grown, industries like agriculture and manufacturing have suffered. Economist Max Cordon (2012) referred to this effect as 'Dutch disease' and warned about its ripple effects. However, other commentators disagree with him. Hambur and Norman (2013) claim the Dutch disease theory is based on simplistic guesswork. Looking at other impacts, Langton and Mazel (2008) claim that the mining boom has damaged communities and living conditions in remote and regional Australia, to the extent that the country is now in the grip of a 'resource curse'. They use the term to describe how mining, as it is currently practised, can lead to poor economic growth, conflict and declining standards of democracy.

The footprints of the resource industry are pervasive throughout the Western Australian physical, political and economic landscape. While the state's economy was once dominated by agriculture, the mining and petroleum industry share of gross state profile has grown from about a fifth ten years ago to about a third in 2013 (Department of Treasury, 2014). The Western Australian government has invested significantly in the industry. According to Peel et al (2014), the big mining states, WA and Queensland, routinely give the resources industry over a billion dollars a year in assistance. Their study, that sought to put a dollar figure on the level of state assistance, concluded that over six years the WA government had given $\$ 6.2$ billion. Their article highlights the way that events that bring the government money, such as profits from privatisation and partnerships deals, are often reported in the media (possibly as a result of media statements being issued), but the cost of supporting the industry are less frequently reported. In their words: 'Often the way budget papers are structured means that the spending that is clearly aimed at benefitting the minerals and fossil fuel industries is not readily identifiable' (Peel et al, 2014, p. 27). 


\section{The Pilbara}

The Pilbara region hosts big players in the resources industry such as Chevron, BHP Billiton, Woodside, Shell, Apache and Rio Tinto, who promote their corporate social responsibility through a substantial glossy literature cache. These volumes of company reports and brochures cite environmental and social studies conducted by researchers who are in most cases contracted by the companies. While these studies may satisfy approval conditions and dazzle the media, they have little academic credibility. Carrington (2013, p. 3) described them as: 'compromised industry-funded research vital to legitimating the resource sector's self-serving knowledge claims.' She states that the unseen costs of mining are borne mostly at a local level by communities on the frontier of the mining boom:

These include rising rates of fatigue-related death and injuries, rising levels of alcohol-fueled violence, illegally erected and unregulated work camps, soaring housing costs and other costs of living, and stretched basic infrastructure undermining the sustainability of these towns. But these costs have generally escaped industry, government and academic scrutiny. (Carrington, 2013, p. 295)

According to Brueckner et al (2013, p. 112), successive State governments have invested considerably in the 'exploitation of the State's natural assets since foundation', while spending little on the communities and towns living in the shadows of major operations. Owen and Kemp (2012) argue that corporate claims about fulfillment of social and environmental obligations are a crafted industry response to opposition to the sector itself, arising from a series of environmentally and socially damaging incidents such as the 1989 Exxon Valdez oil spill. Brueckner et al (2013) examined the 'social licence to operate' sought and won by WA's mining industry, in the context of the state's 'developmentalist' agenda. They drew on the findings of a multi-disciplinary body of research and found significant risks and challenges evident in the environmental, social and economic sustainability of the industry. They take issue with the social licence arguing that a State that is ideologically entwined with resource-led economic growth gives political licence to the industry but fails to demand adherence to social and environmental obligations.

Looking specifically at the town of Onslow, Haslam McKenzie (2013) documented some of the adjustment pressures experienced by Onslow town residents triggered by the establishment of the gas hubs and discusses the strategies employed by the state and local government, the mining companies and the community to enhance the quality of life in the town. She found that the community engagement strategies and the collaborative planning processes were undermined by disconnects between commercial imperatives, governance 
frameworks, investment risk and timeframes. Chapman et al (2014, p. 79) also examined the rapid resource-led development of Onslow, focusing on the failure of timely policy responses that hindered local adjustment and adaptation. They attributed the delays and dissatisfaction to 'governments' inability to respond quickly to the emerging needs... despite the considerable efforts that have gone into problem identification and anticipation, community engagement, and the provision of company funding'.

\section{Tracking Onslow}

Given the contestation about the impacts of extractive industries, in Australia, WA, the Pilbara and specifically in Onslow, the Tracking Onslow project was well positioned to extend public debate by 'giving voice' to a range of people from the community. The project also sought information from key corporate and government stakeholders; and presented it in a format lay readers could understand and respond to (further facilitating public debate). Tracking Onslow was to some extent alone in doing this, as Onslow has no local newspaper, radio station or resident journalists. The closest thing Onslow has had to a local paper is a glossy publication called Inside Ashburton produced by the local government to promote shire activities. Notice boards at the supermarket and formerly at the pub facilitated dissemination of information about local events and services, and the staff of the Onslow tourism office produce a newsletter that is a photocopied compilation of pages submitted by members of the community. Between 2012 and 2015, internet connectivity in Onslow improved dramatically and social media, including Facebook groups, emerged as a vibrant vehicle for communication between members of the Onslow community. The nearest ABC office is in Karratha, three hours' drive away, and Karratha also hosts offices of three regional newspapers. The $\mathrm{ABC}$ and the statewide newspapers rely on the staff in those offices to report on events in Onslow, but these reporters rarely have opportunities to visit or time to establish local contacts. While a few events in Onslow received brief coverage in State-wide media over the course of the Tracking Onslow Project it was, initially, only in response to corporate and government press releases, rarely balanced by other community voices. Frustration at this one-sided style of reporting prompted the Onslow Chamber of Commerce and Industry to hire a media consultant in late 2014 to get their side of the story into the mainstream media. While this is a form of spin in its own right (promoting the case that local businesses should be offered more of the contract work), it went some way towards increasing the diversity of voices people outside of Onslow could hear through mainstream media. The Tracking Onslow project itself also attracted some media coverage, in regional newspapers, and local and national $\mathrm{ABC}$ radio broadcasts which enabled the range of perspectives our 'town square' approach had curated to be shared more widely. 
The use of journalism as a research methodology to document the changes in Onslow was inspired by the academics who have argued that there is potential for journalism to be more widely used as a research methodology in Australia (Lamble, 2004; Nash, 2013; Bacon, 2006). Nash (2013) suggested that academics formulate a definitive definition of journalism as research, so as to engage with the ontological and epistemological systems in operation. In response to these arguments, the Journalism Education and Research Association of Australia (JERAA) released the Journalism Research Australia National Statement, which includes:

Journalism as an academic research discipline contributes to the body of scholarly knowledge about the contexts, tools, creation, distribution, consumption, impacts and social relations of journalism via journalism studies and journalism practice ... Journalism practice is the process by which information is independently researched, gathered, analysed, synthesised and published, or by which innovative approaches to journalism are developed. The Excellence in Research for Australia framework (ERA) acknowledges in-depth, original journalism practice and publication as equivalent to traditional research outputs. (JERAA, 2015)

Bacon (2006) and Nash (2014) have both proposed that journalism better fits the criteria of academic research if it is accompanied by a reflexive exegesis. Mason (2014) also promotes critical reflexivity as a valid method in which to examine journalism from the inside, and suggests this process can facilitate greater understanding of journalism practice and its place in the societal sphere. Her argument builds on Bacon's (2006) assertion that journalism has a lot to do with the day-to-day exercise of power, and that reflexivity about standard journalism practices, such as consideration of whose voices are being privileged (and why), can improve the quality of the work being created and bring new insights. Andrejevic (2008) expands on this in his discussion of Foucault's power/knowledge discourses and argues that through Foucault, journalism can engage in reflexive critique and negotiate relationships of power as instruments of resistance.

In his 1972-1980 writings on truth, power and knowledge, Foucault examined the regimes of truth that regulate societies and power structures. Rather than focusing on the concentrated power that individuals or institutions wield, he explored the invasive mechanisms that entrench power through 'discourse, knowledge and regimes of truth' (1980, p. 30). He argues that, far from being sets of simple ideological statements, discourses actively develop into systems of power that maintain control in society. Although journalism produces discursive statements that invest power in institutions, it can also be a vehicle for resistance and facilitate discontinuity. Nash $(2014$, p. 93) contends that 'the fundamental 
importance of journalism lies in the introduction of the truth object or fact into contemporaneous socio-political discourse, or alternatively, the production of silence about truth objects and facts'.

Foucault proposes that practices of resistance can modify the rules that formulate discursive statements, which are the building blocks of discourses. He calls the modifications 'discontinuities' and says that while they can adapt the structure of a discourse; these practices do not enable us to extricate ourselves from the system. In his words (1980, p. 141): 'One is never outside power, there are no margins for those who break with the system to gambol in. But this does not entail the necessity of accepting an inescapable form of domination.' Power systems are often hard to see and separate from the explicit political/legal framework. It exists in the realm of fluid interpersonal dynamics that enable spin, lobbying and old boy's networks that can be hard to pin down in terms of watchdog identification of wrongdoing. Foucault warns that:

What makes power hold good, what makes it accepted, is simply the fact that it doesn't only weigh on us as a force that says no, but that it traverses and produces things, it induces pleasure, forms knowledge and produces discourse. (Foucault, 1980, p. 119)

The things Chevron produces include glossy brochures, television advertisements and press releases glorifying the project's physical and social achievements. The company also induces pleasure by sponsoring community events such as the Perth International Arts Festival, the Passion of the Pilbara Music and Arts Festival, and the Perth City to Surf fun run. This induction of pleasure and production of things allows Chevron to insert attractive and digestible discursive statements into the field of discourse with the aim of controlling what other stakeholders perceive to be 'truth'. The truth being promoted is a fabric that journalism can pick at by negotiating with other sites of power and giving voice to other players. These practices are modes of resistance.

Foucault (1972) said knowledge can be defined as true or false only within the framework of social systems of truth, which can be changed from the inside. In journalism, knowledge and power are held by those whose social status allows them a voice. Those without a social position or prestige often struggle to have their voices heard in the public sphere. The knowledge they possess is hidden knowledge that Foucault describes as subjugated. In trying to discover and publish 'hidden facts', in order to expose the sequence of actual events, the force journalism often encounters is commonly called 'spin'. Stockwell (2007) described spin as a strategy used by governments (and other powerful entities) in the 'permanent campaign' to retain power. He said it involves attempting to control the news agenda by embellishing some actual events, and hiding others, as part of a bid to construct a favourable meta-narrative. Its entrenchment 
in contemporary Australian news production was documented in the Australian Centre for Independent Journalism's 2010 'Spinning the Media' study. The team looked at 2203 stories from 10 newspapers and found that 55 percent of them were driven by some sort of PR (Bacon et al, 2010). In addition to creating news, spin can also hinder its production. Errington and Miragliotta (2011) decry that the watchdog role has become harder to fulfil because of the increasing power of government media units and advisers, who often place themselves between politicians and journalists. Journalist Margot Kingston (2004, cited in Errington \& Miragliotta, 2011, p.89) calls media advisers 'information blockers, not information providers', while Helen Ester (2007, p. 123) declared that journalists may struggle to: 'withstand the pressures of modern-day government media management and manipulation.'

There is a perception that this pressure is increasing because the sheer number, as well as the professionalism, of media managers is on the rise. PR is described by practitioner and educator Kim Harrison (2011) as the deliberate, planned and sustained effort to establish and maintain 'mutual understanding' between organisations and publics. He teaches that 'framing' is an important strategy in PR that involves inclusion, exclusion and emphasis. Given that it is openly stated that the PR practitioner's job is to control or limit access to information, this article examines how much it influenced the extent to which journalistic practice could succeed in scrutinising government and corporate behaviour in Onslow.

\section{Background information}

Rather than investing in civil infrastructure in the Pilbara, the WA government has in the past opted to negotiate State Agreements with proponents of major resource projects. These State Agreements are made binding by an Act of State Parliament, and generally outline a project's terms and conditions, and investment and operational obligations. However, the Wheatstone project was not underwritten by a State Agreement. Instead it is described and bound by a contract-based State Development Agreement (SDA). This means that the government and corporate partners entered a contractual agreement that is not ratified by an Act of State Parliament. The Ashburton North Strategic Industrial Area (ANSIA) SDA was approved in late 2011 by the State Premier, Colin Barnett, who informed the parliamentary assembly at the time that:

The State Development Agreement negotiated by the State Government ensures important benefits for Western Australians... The project is expected to create 6500 direct and indirect jobs at peak construction and 300 new operational jobs, and to deliver an estimated $\$ 17$ billion to Australian businesses and services over the life of the project... (Parliament of Western Australia, Legislative Assembly, September 27, 2011, p. 7765b) 
As a condition of the ANSIA SDA signed by Chevron, BHP Billiton and their partners, three major investment funds were established, that are the means through which the resource companies are funding efforts to demonstrate corporate social responsibility. The three funds are called the Wheatstone Social Infrastructure Fund (WSIF); the Wheatstone Critical Infrastructure Fund (WCIF); and the BHP Billiton Macedon Social Infrastructure Fund (MSIF). Together they are valued at around $\$ 255$ million.

\section{The article brief and process}

While several major projects for the town had been mooted, members of the community had voiced concern in previous editions of Tracking Onslow about the lack of progress, and questions had arisen about when, and if, the funds would result in positive outcomes for the town. Barndon (2014, p. 6-7) detailed the concerns of Geoff Herbert, president of the Onslow Chamber of Commerce and Industry (OCCI) about Chevron's perceived 'broken promise', and the slow rate of progress of projects. In December 2014 Premier Colin Barnett released a project map through the Department of State Development (DSD) with anticipated timelines and cost projections for 24 projects in Onslow, to be funded entirely or in part through the infrastructure funds (Premier's Office, 2014). This document was the starting point for the lead story for edition six, which sought to establish whether the community was benefiting from this funding by following the money trail.

The first steps in the investigative process were retrieval and examination of primary source material that included; the minutes of Shire of Ashburton council meetings from December 2014 to May 2015; minutes of a January 2015 Department of Planning and Development community meeting; State Parliament Hansard extracts dated May 2012 and August 2013; the 2013-14 Shire of Ashburton Annual Report; the 2010 Shire of Ashburton Onslow Townsite Strategy Background Report; the 2013-14 DSD Annual Report; the 2014 Pilbara Development Commission Profile Report; the Onslow Skate Park Draft Consultation Report and Conceptual Plan; and the DSD list of 24 major projects.

The government agencies on the list of 24 projects were then contacted and cost breakdowns and progress reports were requested. The offices of the Premier, the Opposition Leader and the State Development Shadow Minister, were asked for comment on the progress of the projects in Onslow. Most responses went no further than reiterating the information contained in the documents we had already read. Two questions were sent by phone and email to the office of the Premier asking for clarification of the State and Chevron funding arrangements, and access to the ANSIA SDA was requested. When these requests were denied, Greens MLC Robin Chapple was asked for assistance locating the ANSIA SDA. After trying to access it, his staff responded that the Parliamentary Library was 
unable to provide the document, even to members of Parliament, because it was classified as 'commercial-in-confidence'. Three additional questions were sent to the DSD requesting clarification of Chevron and State funding and for comment on community dissatisfaction with the timing of the projects. Chevron PR liaison officer Kathryn Ackroyd, was sent a request for a more complete breakdown of Chevron's financial commitment in Onslow, as she had previously explained all media inquiries 'must' be channelled through her and vetted by the company's corporate hierarchy in the US. Again this process yielded very little new information.

The office of Nationals MLC Vince Catania was contacted with a request for a breakdown of Onslow Royalties for Regions grants (a form of State government funding for regional development). His office sent the information requested. On-the-record interviews were then conducted with the Shire of Ashburton CEO Neil Hartley, the Shire President Kerry White, the OCCI President Geoff Herbert, BHP Billiton representative Bindi Gove and a number of local community members.

Once the material had been compiled it was fact checked via phone calls with Ackroyd from Chevron and a DSD PR officer. This final check sought to clarify whether sums of money mentioned by some sources and in some documents were included in the totals they had given, or additional to those totals. One of the major sources of confusion was that some financial allocations had been reported several times, so we needed to check if this was repetition or additional allocations.

While the PR staff were friendly, and happy to work with us on fact checking, they did not give any additional information. They were also meticulously clear about which of their comments were 'on' and 'off the record', to the extent of 'insisting' that their names were off the record, and they could only be referred to as spokespeople. For example one email included this line: 'Please understand we have a stringent approvals process here, so all my verbal and email guidance over the last 24 hours to you and Karma has been background confirmation of basic facts. Happy for you to say DSD would not provide a full list of projects and leave it at that' (Personal Communication, DSD spokesperson, 11 July 2015). One of the questions we asked Chevron had to do with the company's long running battle with the Australian Taxation Office in relation to the Gorgon gas project, which is separate from Wheatstone but also in WA's northwest. We deemed the question relevant in the light of Chevron's claim that it was practising corporate social responsibility. Chevron's response was not only deliberately bland, in order to detract from the newsworthiness of the story, but also the PR professional also tried to dissuade us from covering the issue, writing: 'Please find responses to your questions below, all attributable to a company spokesperson. Regarding the ATO case, I do want to make the point 
the case refers to the period 2004-2008. Prior to the final investment decision on the Wheatstone Project. I would question the relevance of this case to Tracking Onslow' (Personal communication, Kathryn Ackroyd/Chevron Spokesperson, 3 July 2015). We published these responses from Chevron in a Q\&A format on page nine of Tracking Onslow, edition six, so readers could see the 'blandness' strategy first hand.

When it came to writing the edition six lead story the 'follow the money trail' theme was incorporated as a narrative device as it enabled sequential revelation of the details we were able to find and incorporation of the roadblocks we encountered into the text. The headline: Show us the $\$ 250$ million; echoes the line 'Show me the money' shouted at full volume in the movie Jerry Maguire (Crowe, 1996). It was hoped that this device would convey a sense of urgency and frustration about the financial secrecy. It should also be noted that, as with most journalism, there were time and space limitations as the article was only allocated five magazine pages and needed to be produced between early June and mid-July, 2015.

We also used extensive quotes from the interview with OCCI president Geoff Herbert, as in articles in previous editions he had been a very vocal critic of Chevron. For example in edition three he was quoted as saying:

\begin{abstract}
Some of these companies are so used to operating in third world countries, like Chevron in Africa, that they have difficulty relating to people and communities. Chevron cannot just ride roughshod over us here and try to appease us with the odd hospital or school like they do overseas. ... People forget that Chevron is a big company with lots of shareholders, and those shareholders want to make money. ... They do not do anything benevolently, ... they only do what they have to. (Barndon, 2013, p. 5).
\end{abstract}

His comments in the final edition interview represented a turnaround from his earlier position and were included at length as they illustrated the shift in his position over time. The numbers we were able to access were presented in a table, that also clearly illustrated the gaps in the information available.

\title{
Discussion
}

The outcome of the journalistic process is an article that explains where some of the money has been spent and allocated, and that challenges corporate and government silence on the remainder. It offers a narrative that differs from the corporate/government story of mutually beneficial development that is showering prosperity on everyone and imposing no costs on the community. Key elements of the story that achieve this are the focus on the secrecy of the ANSIA SDA and the expression of scepticism about the genuineness of the promise to actually spend \$250 million or more on Onslow in the foreseeable future. In doing 
this, it provides a counterpoint for other media that may be seeking to present a balanced or sceptical analysis but perceiving a need for a source of doubt. Perhaps evidencing the power of PR to control the narrative, there has been little media follow-up along these lines. Our unsuccessful quest to fully articulate the spending plan for the $\$ 250$ million has, however, exposed a lack of scrutiny of the figure by journalists at the ABC (New $\$ 41.8 \mathrm{~m}$ hospital, 2014), Seven West Media (Govt announces Onslow upgrades, 2014), and other outlets. No media except Tracking Onslow has questioned the plausibility of the promised spend, or published questions about the protracted delays or the chance that the money may not be forthcoming in the foreseeable future.

The question this project set out to answer is: Can journalism fulfill the watchdog, town square and first draft of history functions amid the spin and power struggles contesting the narrative about Onslow? The answer appears to be yes; the following paragraphs detail why and how in doing so it has functioned as a practice of resistance in a Foucauldian sense.

The watchdog function enshrines the notion: 'that the media will stand on guard over democracy, closely watching and evaluating the political decision makers' (Errington \& Miragliotta, 2011, p. 8). By monitoring, questioning and documenting the responses of the political and economic decision makers on community (Herbert), local (Hartley/White), corporate (Ackroyd/Gove) and state (Premier/DSD) levels, the journalism fulfilled this function. Although some of the responses reported were refusals or contained no new information, reporting of this obfuscation is congruent with the exposition of political behaviour.

According to Errington and Miragliotta, (2011, p. 9), the town square function enables public dialogue in: 'a marketplace of ideas in which opinions can be debated, contested and ultimately shared.' While the lead story for edition six only featured the voices of people in positions of power, elsewhere in Tracking Onslow voices of community members were liberally used. Each magazine also included a six to eight page section devoted to recording the views of people we met in Onslow (in shops, on walks through town and while pursuing other stories). Efforts were made to include people with a wide range of demographic characteristics. A potential problem with this approach was verification of their truth claims. We were consequently careful to label this section 'In Your Words', to use quotation style carefully and we ran the following disclaimer:

We know that not everyone in Onslow agrees with each other, but we seek to allow everyone a space to speak through our pages. Sometimes opinions are based on misunderstood facts and so some of the things people say may not be true.

We can't vouch for the truth of what people we spoke to said, but we have faithfully recorded it so that this edition is a true record of what was being said in and about Onslow in mid-late 2014. (Davies, 2014b, p. 1) 
When de Burgh (2000, p. 3) refers to journalism as: 'the first rough draft of history', it is in reference to the similarities between the tasks of the journalist and the historian. While details about the changes in Onslow exist in the primary source documents and academic reports we accessed, Tracking Onslow is an illustrated, curated collection that brings together the key points and documents the community responses to those points. Had this work not been done, the voices of people who are not in positions of power would be inaccessible to future historians. To ensure that the collection is accessible it has been lodged in the national, state and university libraries.

In a Foucauldian sense, this process has introduced knowledge into the discursive field, and that is an act of resistance. When Foucault talks of resistance to power, he declares that who controls knowledge controls power. By influencing knowledge, power has been modified and the watchdog role has been fulfilled. As the watchdog brings in other voices to question the 'truth' provided by the powerful players, it plays the town square role, and in doing so creates a first draft of history. Therefore contemporary Australian journalism (as described by Lamble, 2004) can fulfill the functions of journalism described by Errington and Miragliotta (2011) in a resource town amid corporate and government power struggles and bids to control the narrative. And, subsequently, projects like Tracking Onslow can fill functional gaps in contemporary Australian journalism practice and process.

\section{The article (on pages 3-7) is here:}

http://issuu.com/ecujournalismperth/docs/onslow_mid_2015_for_issuu/1 (It includes a full page table not included in this version.) 


\section{Tracking Onslow}
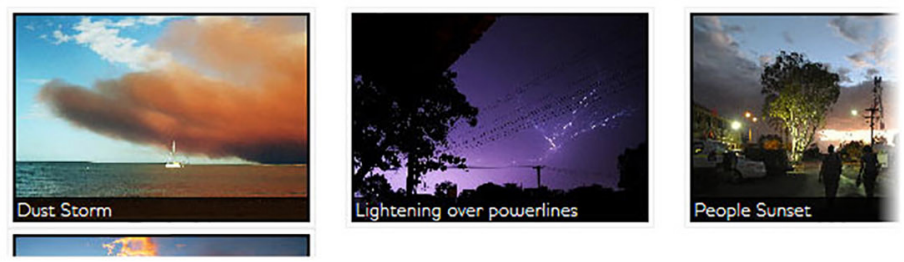

ECU's Tracking Onslow Project is progressing well, providing insight into the impact major resource projects have on their host communities.

In addition to being the subject of a 2013 Vice-Chancellor's Award for community engagement, it has received media coverage in the Pilbara News, and on ABC Northwest Radio and Radio National.

\section{Part 2: The article}

\section{Show us the $\$ 250$ million}

The people in Onslow are tired of promises. Big dollar figures have been bandied about since news of the gas hubs first came to town. The figure $\$ 250$ million is commonly quoted as the amount being spent in the community in connection with Chevron's Wheatstone LNG project and so we tried to track it down. Where is the money, what is it being spent on and when?

W

HILE the $\$ 250$ million figure appears in Chevron, State government and Shire documents, pinning down what it is being spent on is not an easy task. Most often the answer referred to a list of 24 projects that are in varying stages of development.

Asked for a list of figures that add up to $\$ 250$ million, the Department of State Development (DSD) refused, explaining that not all listed projects have a public cost figure yet. We understand that price projections for future projects can be difficult, but we wondered where the total came from (if the figures that add up to it are unknown) and what will happen to the remainder if some projects are cancelled or completed under budget.

The $\$ 250$ million is the sum of a list of numbers contained in a document called the 'State Development Agreement' which is not publicly available as it is 'commercial in confidence' (and not even members of parliament can access it). 
The DSD, however, stressed that the $\$ 250$ million is all coming from Chevron and that there is an additional $\$ 70$ million in State government spending earmarked for Onslow.

The list of 24 projects, published in December 2014, outlines delivery timelines for many of the Onslow projects. Announcing it, Premier and State Development Minister Colin Barnett pledged that most of the projects would be completed over the next three to four years, saying: 'Almost a dozen State agencies are involved in delivering these projects to ensure that the Onslow community directly benefits from major nearby projects like Wheatstone and [BHP Billiton's] Macedon.'

The State government, Shire of Ashburton, Chevron Australia and BHP Billiton are funding the 24 projects. The

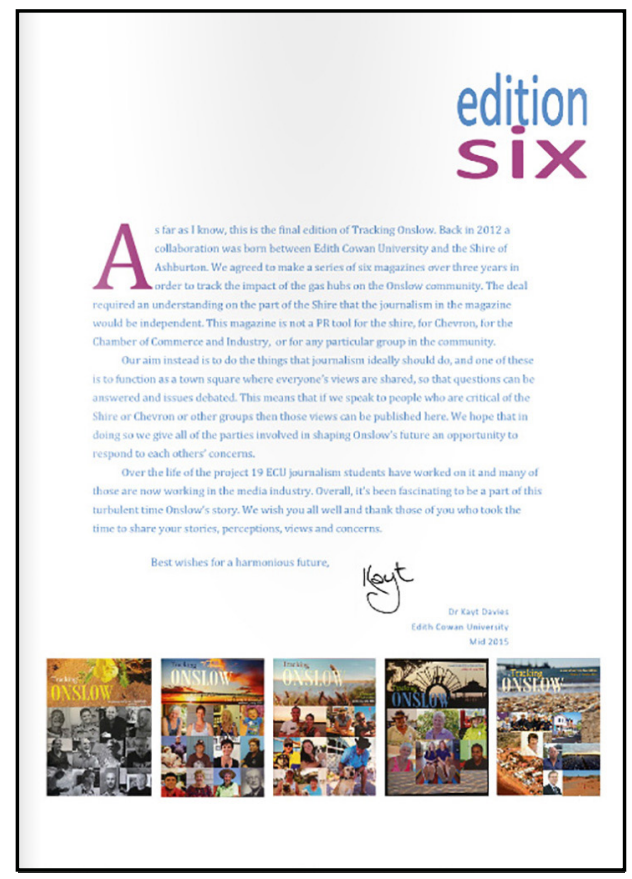
Shire is responsible for delivery of 11 of them, and the State government for 13 . The BHP Billiton contribution is $\$ 5$ million for the skate park and basketball stadium.

Having watched the progress of the spending, some delays are evident. The swimming pool is listed on the December document as due for completion in late 2016. But according to Ashburton CEO Neil Hartley, it is now scheduled for construction between early-2016 and mid-2017. The basketball stadium and skate park have also moved forward from early-2015/mid-2015 to late-2015/mid-2016.

Bindi Gove from BHP Billiton said the company had been ready to spend the $\$ 5$ million it has committed to that project for some time, and that the delays were to do with Shire processes. Ashburton Shire president Kerry White said perceptions that the pledged projects were behind schedule were unwarranted, as significant behind the scenes work had been done to scope, plan and cost them and other external factors had affected the delivery timeline for projects.

According to Mrs White, the projects are a high priority for the Onslow community, and the Shire is investing significant resources to see them delivered. A spokesperson for the Department of State Development (DSD) said that the Shire of Ashburton and a number of State government agencies were 'working diligently to deliver more than 20 community and critical infrastructure projects for Onslow'. The department is coordinating many of these projects. She added that five projects were completed between 2012 and 2014, and that two projects were completed this year.

The big ticket item Chevron is spending on is a power and desalination facility for which public costing is yet to be released, although according to the DSD 2013-14 
annual report 'engineering design and approvals for these projects are progressing and construction of the first stage (water storage tanks) is now underway'.

The report said that in addition to this project Chevron was contributing a 'further $\$ 121$ million' for infrastructure projects. The spokesperson added that Chevron is contributing a further $\$ 66$ million, which along with $\$ 10$ million from Royalties for Regions funding, has been allocated for the community projects being developed by the Shire.

This $\$ 66$ million is in addition to the previous $\$ 121$ million. We calculate that if Chevron's spend is around $\$ 250$ million, and $\$ 66$ million is for community projects and $\$ 121$ million is for infrastructure projects, the power/desal plant seems to be costing at least $\$ 63$ million, although the DSD would not confirm this figure. Chevron's media releases have confirmed the company is funding both projects [power and desal] and that they will take Chevron's total contribution to more than $\$ 250$ million.

In terms of the State government spend, there is the $\$ 10$ million of Royalties for Regions funding towards the Shire-run projects, as well as $\$ 10$ million for the Cane River Bore-field Upgrade and \$19.8 million for the hospital also from Royalties for Regions; and the State Government pitched in \$13 million toward the airport, bringing the visible government total to around \$53 million. The DSD spokesperson said that "circa $\$ 70$ million from the State government" was being spent, so there is $\$ 17$ million of yet-to-be-made-public State government funding presumably involved in the 24 projects.

While the $\$ 250$ million+ from Chevron is clearly Wheatstone related, working out whether the Government's $\$ 70$ million is specifically being given to Onslow because of Wheatstone, as some kind of compensation, is more complicated. This is because it is not clear whether the money was heading to Onslow anyway.

For example, commenting in December 2014 on the $\$ 19.8$ million State government investment in the $\$ 41.8$ million new Onslow hospital, Regional Development Minister Terry Redman said the hospital upgrade was part of the $\$ 161$ million Royalties for Regions North West Health Initiative that is working to cater for expanding populations in the north of the State. He added that improvements to service delivery and health infrastructure aim to enable more patients to be treated regionally, creating community satisfaction and building sustainability in the region.

Onslow Chamber of Commerce and Industry $(\mathrm{OCCl})$ president Geoff Herbert believes the Shire is mainly responsible for the slow rate of progress. 'The problem with the Shire is that they have no external project management team,' he complained.

'They handle these projects themselves and struggle to deliver things because they are inefficient. They don't have enough staff to deal with all the demands. Local government has so many levels of compliance to get through, it is slow.'

Despite that concern, Mr Herbert expressed optimism about the direction the town is going in, and said the only pitfalls are that the local council is becoming 'more of a basket case', and the expansion of the Light Industrial Area (LIA) is 
still needed. Once a fierce critic of Chevron's lack of commitment to the Onslow community, Mr Herbert said that recently Chevron's community liaison team has made real efforts to bridge the gap between the corporate and community reality of Chevron's business. He thought this may be due in part to OCCl's decision last year to hire a media consultant to apply pressure to Chevron and the State government in the wake of the events of mid-2014.

He said: 'They've got a big company out there, and now you can see what they are actually building, they're not here to solve all our social problems they are here to build that plant and process gas.'

He explained that most of the anger directed at Chevron after it received approval from the Premier to build its worker accommodation near the plant rather than in town, had died down, and that Chevron was now seen to be more on board with the community.

He said this was due to better consultation with local businesses. Now when a contract needs to be filled Chevron flies their three preferred tenderers to Onslow and 'we have a big event down at the Business Hub, and all our businesses get to come with their capability statements and meet them and hit them up and tell them who they are.' He said: 'We're not asking for free kicks, we are just asking for access to those connections early on, to have a level playing field.'

He continued: 'What would happen before is the contractors would do all their pricing and hiring in Perth, then rock up here and see we have businesses like signwriting and building and plumbing here already, and they could have saved a fortune if they had known.'

According to Mr Herbert, the West Pilbara Business Support Program that Chevron sponsors is so busy it just employed two new people to help local businesses build their capabilities. Membership of that programme is now up to 116 .

He said Chevron also sponsors the Industry Capability Network (ICN), which flew in an expert for a week to meet local businesses and prepare their profiles for listing on the ICN Onslow On-line Business Directory. The profiles were also distributed to the first-tier contractors on-site at Wheatstone.

Mr Herbert also praised the State government. 'The DSD has also come to the table for the first time ever and are working with us by sending tenders to us and referencing the Onslow ICN. So for that $\$ 250$ million, from both levels, Onslow businesses are finally getting a fair go at it. The only one that lets us down is local government.'

A spokesperson for Chevron told Tracking Onslow the company has a clear interest in ensuring Onslow remains a vibrant and sustainable regional community, based on the company's long-standing philosophy that fosters local partnerships to ensure delivery of sustainable outcomes. Chevron has established an office in town, at 16 Second Ave, staffed by members of the community engagement team who work to update the community on the project and answer their questions and concerns.

Chevron said: 'We continue to work with our contractors and local community and business stakeholders to ensure the Wheatstone workforce makes a positive contribution to Onslow, including through participation in volunteering, 
recreational activities and patronage of local businesses. With our Wheatstone Project joint venture participants, we have committed more than $\$ 250$ million to social and critical infrastructure projects in Onslow.'

Chevron now offers bus tours of the construction site, which provides an opportunity for people to see the Wheatstone Project for themselves. The tour is certainly an eye opener, and the massive reach and scope of construction is overwhelming yet impressive.

Mr Herbert believes that in a business sense, where once the whole Wheatstone project appeared to be a massive failure for the town, it is now looking to be a massive success. Through the $\mathrm{OCCl}$ he is preparing a 'lessons learnt' business investment document to inform the rest of Australia how business can operate smoothly with industry, in a circumstance like this. He believes it is important to show that there is a success story among the negative press stifling the North-West and other mining regions in Australia.

'We are one of the very few towns that has a very bright future for the next ten years, and that needs to be talked up to inspire confidence, both for business and investment. There's so much news about the end of the mining boom, but this region still needs investors to invest.'

Whether or not the Chevron and government spend ends up equalling $\$ 320$ million (which is $\$ 70$ million $+\$ 250$ million) will take some time to assess, as many of the projects have open-ended dates and are dependent on future population growth and demand. Estimating the current population of Onslow to be about 1000 , the $\$ 250 \mathrm{~m}$ represents a spend of about $\$ 250,000$ per resident. While it will be good if it happens, we wonder whether Chevron might have more easily won social licence to operate by simply writing them cheques.

\section{References}

Andrejevic, M. (2008). Theory review power, knowledge and governance: Foucault's relevance to journalism studies. Journalism Studies, 9(4), 605-614.

Bacon, W. (2006). Journalism as research? Australian Journalism Review, 28(2), 147-157 Bacon, W., Loh, M., Taylor, A., Pavey, S. (2010). Spinning the media: Key findings in a week in the life of the media, Crikey, 15 March 2010.

Barndon, K. (2013). Boomtown businesses. Tracking Onslow Magazine, 3, 3-5.

Barndon, K. (2014). Has Onslow missed the boat? Tracking Onslow Magazine, 4, 6-8. Barnett, C. (2010, February 23). Premier's statement (to the WA Parliament). Retrieved from www.mediastatements.wa.gov.au/Pages/Barnett/2010/02/Premier's-statement.aspx

Brueckner, M., Durey, A., Mayes, R., \& Pforr, C. (2013). The mining boom and Western Australia's changing landscape: Towards sustainability or business as usual? Rural Society Journal, 22(2), 111-124.

Buswell, T. (2013, January 29). WA economic growth twice as fast as the nation. [Media Release.] Retrieved from www.mediastatements.wa.gov.au/Pages/Barnett/2013/01/ WA-economic-growth-twice-as-fast-as-the-nation.aspx

Carrington, K. (2013) Corporate, risk, mining camps and knowledge/power. In Carrington, K., Ball, M., O'Brien, E., \& Tauri, J.(Eds.) Crime, justice and social democracy: International perspectives (pp. 295-314). London: Palgrave MacMillan. 
Carrington, K., \& Pereira, M. (2011). Assessing the social impacts of the resources boom on rural communities. Rural Society, 21(1), 2-20. doi:10.5172/rsj.2011.21.1.2

Chapman, R., Tonts, M., \& Plummer, P. (2014). Resource development, local adjustment, and regional policy: Resolving the problem of rapid growth in the Pilbara, Western Australia. Journal of Rural and Community Development, 9(1), 72-86.

Corden, W. M. (2012). Dutch Disease in Australia: policy options for a three speed economy. The Australian Economic Review, 45(3), 290-304.

Crowe, C. (Producer \& Director). (1996). Jerry Maguire [Motion Picture]. United States: Gracie Films.

Davies, K. (2015). Editorial letter. Tracking Onslow Magazine, 6, p.1.

Davies, K. (2014a). Tracking Onslow: Taking journalism out of the classroom and the newsroom. Journalism Education, 3(1), 88-101.

Davies, K. (2014b). Editorial letter. Tracking Onslow Magazine, 5, p. 1.

de Burgh, H. (2000). Investigative journalism: Context and practice. New York: Routledge.

Department of Treasury (2014). The structure of the Western Australian economy. Retrieved from www.treasury.wa.gov.au/uploadedFiles/_Treasury/Publications/2014 Structure of the Economy.pdf

Downes, P., Hanslow, K. \& Tulip, P. (2014). The effect of the mining boom on the Australian economy: Research discussion paper. Canberra: Reserve Bank of Australia. Retrieved from www.rba.gov.au/publications/rdp/2014/pdf/rdp2014-08.pdf

Errington, W. \& Miragliotta, N. (2011). Media and politics: An introduction. (2nd Ed.). Melbourne: OUP.

Ester, H. (2007) The media. In C. Hamilton and S. Maddison (Eds.), Silencing dissent. (pp. 101-123). Sydney: Allen \& Unwin.

Foucault, M. (1980). Power/knowledge: Selected interviews and other writings, 19721977. New York: Pantheon Books.

Foucault, M. (1972). The archaeology of knowledge. New York: Harper and Row.

Franklin, B., Hamer, M., Kinsey, M. And Richardson, J. (2005). Key concepts in journalism studies. London: Sage Publications.

Govt announces Onslow upgrades. (2014, December 9). Seven West Media. Retrieved from https://au.news.yahoo.com/thewest/wa/a/25725086/govt-announces-onslowupgrades/

Grudnoff, M. (2013). Still beating around the bush. Canberra: The Australia Institute. Retrieved from www.tai.org.au/node/1948

Hambur, J. R., \& Norman, N. R. (2013). Sector-specific effects of the Australian mining boom: Dutch disease or Dutch delight? In Proceedings of the Cambridge Business \& Economics Conference, Murray Edwards College, Cambridge.

Harrison, K. (2011). Strategic public relations: A practical guide to success. South Yarra, Australia: Palgrave McMillan Publishers Australia.

Haslam Mckenzie, F. (2013). Delivering enduring benefits from a gas development: Governance and planning challenges in remote Western Australia. Australian Geographer, 44(3), 341-358.

JERAA (2015). Journalism Research Australia National Statement. Retrieved from http://jeaa.org.au/research/

Knight, A. (2000). On-line investigative journalism. Australian Journalism Review, $22(2), 45-58$.

Lamble, S. (2004). Documenting the methodology of journalism. Australian Journalism Review, 26(1), 85-106. 
Lamble, S. (2013). News as it happens: An introduction to journalism. (2nd Ed.). Melbourne: OUP.

Langton, M., \& Mazel, O. (2008). Poverty in the midst of plenty: Aboriginal people, the 'resource curse' and Australia's mining boom. Journal of Energy and Natural Resources Law, 26(1), 31-65.

Mason, B. (2014). Journalism practice and critical reflexivity: A death in custody interview. Pacific Journalism Review, 20(1), 158-179.

Nash, C. (2013). Journalism as a research discipline. Pacific Journalism Review, 19(2), 123-135.

Nash, C. (2014). Research degrees in journalism: What is an exegesis? Pacific Journalism Review, 20(1), 76-98.

New $\$ 41.8 \mathrm{~m}$ hospital for Onslow funded by Chevron and West Australian Government. (December 9, 2014) $A B C$. Retrieved from www.abc.net.au/news/2014-12-09/newonslow-hospital-being-part-funded-by-chevron/5954976

Ottaviano, C. (2012). Managing the money. Tracking Onslow Magazine, 1, 28-30.

Owen, J. R., \& Kemp, D. (2012). Social licence and mining: a critical perspective. Resources Policy, 31(1), 34-36.

Parliament of Western Australia, Legislative Assembly, (2011) Parliamentary debates (Official Hansard). Retrieved from www.parliament.wa.gov.au/Hansard\%5Chansard. nsf/0/bef665d65eed06b24825791b0028ef0d/\$FILE/A38\%20S1\%2020110927\%20 p7765b-7765b.pdf

Peel, M., Campbell, R., \& Denniss, R. (2014). Mining the age of entitlement. The Australia Institute. Retrieved from www.tai.org.au/content/mining-age-entitlement

Premier's Office. (2014). Massive community investment benefits Onslow [Press Release]. Retrieved from www.mediastatements.wa.gov.au/Pages/Barnett/2014/12/ Massive-community-investment-benefits-Onslow.aspx

Powell, K. (2013). Reimagining the town centre. Tracking Onslow Magazine, 3, 12-13. Schultz, J. (1998). Reviving the fourth estate: Democracy, accountability and the media. Cambridge: University Press.

Shann, E. (2012). Maximimizing growth in a mining boom: Public policy analysis for the minerals council of Australia. Sydney: MInerals Council Of Australia. Retrieved from www.minerals.org.au/file_upload/files/publications/mca_maximising_growth in_a_mining_boom_FINAL.p $\overline{d f}$

Stockwe-ll, S. (2007). Spin doctors, citizens and democracy. In S. Young (Ed.). Government communication in Australia (pp. 130-143). Melbourne: Cambridge University Press.

Dr Kayt Davies is a senior lecturer in journalism at Edith Cowan University, Perth. She is also an advocate for journalism practice as a research methodology and is editor of Journalism Research, an online journal 'pioneering the use of journalism as a research methodology': researchjournalism.wordpress.com k.davies@ecu.edu.au

Karma Barndon was an undergraduate and postgraduate student working on the Tracking Onslow project, and is now a journalist at Aspermont, a Perth-based business media company. 